\title{
Physiological potential of Brachiaria brizantha cv. Marandu seeds kept in contact with phosphatic fertilizers ${ }^{1}$
}

\begin{abstract}
Amanda Ribeiro Peres ${ }^{2}$, Gisele Herbst Vazquez ${ }^{2 *}$, Renata Danielle Cardoso ${ }^{2}$
ABSTRACT - The effect of mixture of seeds of Brachiaria brizantha, cv. Marandu, with different sources, granulometry, and phosphatic fertilizer doses during various periods of exposure on the physiological potential of the seeds has been assessed. The treatments consisted in seed exposure during periods of $0,3,6,12,24,36,48,72,96$, and $120 \mathrm{~h}$ to the following fertilizers: ground granulated single superphosphate (SS), and powdered (SSp); and ground granulated ammonium monophosphate (AMP), at doses of 40 and $80 \mathrm{~kg} \mathrm{P}_{2} \mathrm{O}_{5} \mathrm{ha}^{-1}$. Tests of germination, tetrazolium, moisture content, and vigor (first count, electrical conductivity, emergence, emergence speed, and fresh mass of seedlings) were performed. It has been concluded that seed physiological potential of $B$. brizantha $\mathrm{cv}$. Marandu is reduced with increase on the exposure period to phosphatic fertilizer. Such effect, however, is dependent on the product source, granulometry, and dose. SSp was the most harmful to seeds, followed by SSp and AMP, respectively. Moreover, considering a $60 \%$ germination rate as acceptable, it may be inferred that seeds can be kept in contact with AMP and SSp, in dose of $80 \mathrm{~kg}$ of $\mathrm{P}_{2} \mathrm{O}_{5}$ $\mathrm{ha}^{-1}$, respectively, for periods of 71.2 and 16.2 hours.
\end{abstract}

Index terms: phosphorus, seed-fertilizer mixture, exposure period, vigor.

\section{Potencial fisiológico de sementes de Brachiaria brizantha cv. Marandu mantidas em contato com fertilizantes fosfatados}

\begin{abstract}
RESUMO - Foi avaliado o efeito da mistura de sementes de Brachiaria brizantha cv. Marandu com diferentes fontes, granulometria e doses de fertilizantes fosfatados por diversos períodos de exposição sobre o potencial fisiológico das sementes. Os tratamentos foram constituídos de exposição das sementes por períodos de $0,3,6,12,24,36,48,72$, 96 e 120 horas aos seguintes fertilizantes: superfosfato simples granulado moído (SS) e em pó (SSp); e monofosfato de amônio granulado moído (MAP), nas doses de $40 \mathrm{~kg}$ e $80 \mathrm{~kg}$ de $\mathrm{P}_{2} \mathrm{O}_{5} \mathrm{ha}^{-1}$. Foram realizados testes de germinação, tetrazólio, grau de umidade e vigor (primeira contagem, condutividade elétrica, emergência, velocidade de emergência e massa fresca de plântulas). Concluiu-se que o potencial fisiológico das sementes de $B$. brizantha, cv. Marandu é reduzido com o aumento do período de exposição com fertilizante fosfatado. Entretanto, o efeito é dependente da fonte, da granulometria e da dose. SSp foi o mais prejudicial à semente, seguido de SS e MAP, respectivamente. Além disso, considerando como aceitável uma germinação de $60 \%$, é possível inferir que as sementes podem ser

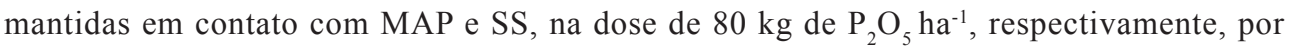
períodos de 71,2 e 16,2 horas.
\end{abstract}

Termos para indexação: fósforo, mistura adubo-semente, período de exposição, vigor.

\footnotetext{
${ }^{1}$ Submitted on 09/04/2011. Accepted for publication on 01/20/2012.

${ }^{2}$ UNICASTELO, Caixa Postal 121, 15600-000-Fernandópolis, SP, Brasil.

*Corresponding author <gisele-agro@uol.com.br>
} 


\section{Introduction}

Although Brazil possess the fourth largest worldwide pasture area, the use of these areas has been performed in intensive and exploitative manner (ANUALPEC, 2011). In Brazil, from 174 million hectares occupied by pastures (IBGE, 2010) approximately $70 \%$ is cultivated with grasses from genus Brachiaria (Barbosa, 2006). However, 60\% of these areas are in process of degradation (Anualpec, 2011), since that, in their majority, such areas were implanted in low natural fertility soils, or that so became, due to inadequate agricultural practices (Cavariani et al., 1994). Brazilian soils are naturally deficient in phosphorus, what jointly with their natural acidity, contributes for the low productive indexes of nationwide livestock rearing; what makes the phosphatic fertilization an essential practice for production and for sustainability of pasture areas (Nascimento et al., 2002).

Thus, in establishing a pasture it is necessary to consider; besides amount of fertilizer needed to supply the crop requirements; that a good preparation of soil, the use of high quality seeds, and an evenly and quantitatively correct seeds distribution are needed to guarantee an adequate plant population per area.

There are many farmers, however, who do not have specific fertilizer/seed spreaders for pasture seeds; and in addition, the small size of brachiaria seeds, and other forage grasses, makes their even distribution even more difficult. This way, the mixture of forage seeds with phosphatic fertilizers at moment of sowing is an old cultural practice in which the fertilizer acts as the seed conveyor, besides serving as fertilization in the sowing procedure; and that is still nowadays used in Brazilian agriculture (Soratto et al., 2003).

With publication of the Normative Instruction no. 30 of $05 / 30 / 2008$, by the Ministry of Agriculture, Livestock and Food Supply, that established norms and standards for production and commercialization of seeds of grasses and leguminous forage of tropical climate, there was an increase in the minimum standards of physical purity for commercialization of such seeds. For seeds of Brachiaria brizantha, the standard was from $40 \%$ to $80 \%$ in the basic classes $\mathrm{C} 1$ and $\mathrm{C} 2$; and $60 \%$ in the classes $\mathrm{S} 1$ and S2. Improvements on seed standards, with consequent increases on standard of physical purity, contributes for better pure live seed value and, from the agronomic and economical viewpoints, are very positive since it make possible a reduction on amount of weed seeds in grasses seed lots. It also allows higher uniformity of sowing procedure, and even aids on economy for transportation of these materials. From another viewpoint, however, requires higher efficiency on distributing seeds in the field, once the sowing rate is smaller, and even worsens, when adequate machines are not available for the procedure.

The objective of this study was to assess effect of mixture of seeds of Brachiaria brizantha, cv. Marandu, with different sources, granulometry, and doses of phosphatic fertilizers during different contact periods on the physiological potential of the seeds.

\section{Material and Methods}

The research work was carried out from April to October, 2010, in the Seed Analysis Laboratory of University Camilo Castelo Branco, Campus of Fernandópolis, State of São Paulo.

Seeds of brachiaria (Brachiaria brizantha (Hochst. ex A. Rich.) Stapf), cv. Marandu, provided by the Semembrás Seed Company, and produced in 2008/2009 was used in the experiment. The seeds had $60 \%$ physical purity and $80 \%$ germination, thus resulting in $48 \%$ of cultural value (PLS), and $9.23 \%$ moisture content.

The following fertilizers were used: ground granulated single superphosphate (SS), single superphosphate powdered (SSp); and ground granulated ammonium monophosphate (AMP); provided by Heringer Fertilizers Company. To facilitate the subsequent separation of seeds, the granulated fertilizers SS and AMP were initially ground in a forage chopper and disintegrator, CREMASCO $^{\circledR}$ brand, model DP-4, using a $5 \mathrm{~mm}$ mesh sieve. The $\mathrm{pH}$ and salinity values of fertilizers (measured through electrical conductivity) are shown on Table 1.

A completely randomized experimental design, with four replications and the treatments arranged in a $10 \times 3$ x 2 factorial scheme [10 exposure periods $(0,3,6,12,24$, $36,48,72,96$, and 120 hours) $x 3$ sources of fertilizers (SS, $\mathrm{SSP}$, and AMP) x 2 doses of $\mathrm{P}_{2} \mathrm{O}_{5} \mathrm{ha}^{-1}(40 \mathrm{~kg}$ and $80 \mathrm{~kg})$ ] were used in the experiment. The adopted doses were based on recommendations of Werner et al. (1997) for forage grasses; where: for soils with low phosphorus content ( 0 to $6 \mathrm{mg} \mathrm{dm}^{-3}$ ); the recommendation is $80 \mathrm{~kg}$ of $\mathrm{P}_{2} \mathrm{O}_{5} \mathrm{ha}^{-1}$; and for soils with median phosphorus content ( 15 to $40 \mathrm{mg} \mathrm{dm}^{-3}$ ); the recommendation is of $40 \mathrm{~kg}$ of $\mathrm{P}_{2} \mathrm{O}_{5} \mathrm{ha}^{-1}$.

This manner, considering the cultural value used (48\%) and the ideal rate of sowing of $5 \mathrm{~kg} \mathrm{ha}^{-1}$ of pure and viable seeds (PVS) recommended by EMBRAPA (2004), was defined the ratio of $25 \mathrm{~g}$ of seeds for SS and SSp (content 
of $19 \% \mathrm{P}_{2} \mathrm{O}_{5}$ ) and the values reached 505.2 and $1,010.5 \mathrm{~g}$ : what results in 210.53 and $421.05 \mathrm{~kg} \mathrm{ha}^{-1}(40 \mathrm{~kg}$ e $80 \mathrm{~kg}$ de $\mathrm{P}_{2} \mathrm{O}_{5}$ ha $^{-1}$ ), respectively. For the source AMP (content of $52 \%$ of $\mathrm{P}_{2} \mathrm{O}_{5}$ ), the values were 184.6 and $369.2 \mathrm{~g}$; thus resulting in 76.92 and $153.85 \mathrm{~kg} \mathrm{ha}^{-1}(40 \mathrm{~kg}$ and $80 \mathrm{~kg}$ of $\mathrm{P}_{2} \mathrm{O}_{5}$ ha $\left.^{-1}\right)$, respectively.

Table 1. Values of $\mathrm{pH}$ and electrical conductivity of water $\left(\mathrm{H}_{2} \mathrm{O}\right)$ and of the fertilizers: ground granulated ammonium monophosphate (AMP); ground granulated single superphosphate (SS); and single superphosphate powdered (SSp).

\begin{tabular}{|c|c|c|c|c|}
\hline Determinations & $\mathrm{H}_{2} \mathrm{O}$ & AMP & SS & $\mathrm{SSp}$ \\
\hline $\mathrm{pH}$ in water ${ }^{(1)}$ & 7.3 & 5.28 & 4.30 & 3.34 \\
\hline $\begin{array}{l}\text { Electrical conductivity } \\
\left(\mu \mathrm{S} \mathrm{cm}^{-1}\right)^{(1)}\end{array}$ & 1.43 & 827 & 742 & 920 \\
\hline
\end{tabular}

(1) Proportion of $1 \mathrm{~g}$ of fertilizer for $1 \mathrm{~L}$ of deionized water.

Seeds were homogeneously mixed with doses of each phosphatic fertilizer and stored into Kraft ${ }^{\circledR}$ paper bags $(17.5 \mathrm{~cm}$ wide and $41.5 \mathrm{~cm}$ long) under controlled environmental conditions $\left(22{ }^{\circ} \mathrm{C}\right.$ to $25{ }^{\circ} \mathrm{C}$ and $45 \%$ to $55 \%$ RH). After exposing seeds to fertilizers during the pre-determined periods, these were separated with the aid of tweezers and 4 and $2 \mathrm{~mm}$ mesh screens. Afterwards, moisture content of seeds was determined and tests of percentage of: germination; viability (tetrazolium); and vigor (first count, electrical conductivity, emergence percentage, emergence speed index, and fresh mass of seedling) were applied.

Determination of moisture content (MC) was performed by the oven method at $105 \pm 3{ }^{\circ} \mathrm{C}$, during $24 \mathrm{~h}$, according to Rules for Seed Testing (Brasil, 2009), using two replications of approximately $4.0 \mathrm{~g}$ of seeds each, for each treatment. Results were expressed as mean percentage, in wet basis.

The germination test $(\mathrm{G})$ was performed according to methodology described in Brasil (2009), with four replications of 50 seeds each, for each treatment. Seeds of each replication were evenly distributed into $11 \mathrm{~cm} \times 11 \mathrm{~cm} \times 3.5 \mathrm{~cm}$ transparent plastic germination boxes (gerbox) containing two sheets of filter paper previously moistened with a $0.2 \% \mathrm{KNO}_{3}$ solution, in a ratio equivalent to 2.5 times the mass of dry substrate. Immediately after, the gerbox were lidded and placed into a germination chamber, FANEM brand, model $347 \mathrm{CDG}$, under alternated temperature of $15{ }^{\circ} \mathrm{C}$ and $35^{\circ} \mathrm{C}$, and $8 / 16 \mathrm{~h}$ photoperiod $\left(8 \mathrm{~h}\right.$ at $35^{\circ} \mathrm{C}$, under fluorescent light; and $16 \mathrm{~h}$ at $15^{\circ} \mathrm{C}$, in the dark), adding pure distilled $\mathrm{H}_{2} \mathrm{O}$ to substrate when needed. The counting was performed at seven and 21 days after starting test. Results were expressed in percentage of normal seedlings; and data from first count ( $7^{\text {th }}$ day) were used as results for the test of first count of germination (FC).

To assess viability of seeds, the tetrazolium test $(\mathrm{Tz})$ was employed by using two replications of 50 seeds each, for each treatment. Initially, circa 150 seeds were wrapped in Germitest ${ }^{\circledR}$ paper, immersed in water for $12 \mathrm{~h}$, and maintained into incubator at $30{ }^{\circ} \mathrm{C}$. After completion of the hydration periods, each seed was sectioned along the embryo; discarding one half and immerging the other half into a $1 \%$ solution of 2, 3, 5 triphenyl tetrazolium chloride, during $3 \mathrm{~h}$, at $30{ }^{\circ} \mathrm{C}$, in the dark (Brasil, 2009). The assessment of the seed halves was performed with the aid of a 3-X magnifying lens, Ramsor brand, model LL-24, fixed in the work bench. Assessment criteria followed the recommendations of RSA (Brasil, 2009); where seeds are sorted as viable and non-viable; according to the maximum area allowed for non-stained tissue ( $1 / 3$ of radicle, measured starting from extremity).

The electrical conductivity (EC) was determined in four subsamples of 50 seeds each, for each treatment. Seeds were weighed with a $0.0001 \mathrm{~g}$ precision analytical balance; placed into $200 \mathrm{~mL}$ plastic cups; covered with $75 \mathrm{~mL}$ of deionized water; and then kept into a BOD type incubation chamber, at $25^{\circ} \mathrm{C}$, for $24 \mathrm{~h}$. After such period, the electrical conductivity of solution was measured with the aid of a conductivimeter, DIGIMED $^{\circledR}$ brand, model DM-31. Results were expressed in $\mu \mathrm{S} \mathrm{cm}^{-1} \mathrm{~g}^{-1}$ of seeds (Vieira and Krzyzanowski, 1999).

The test of emergence of seedlings (ES) was carried out in the greenhouse; with four replications of 50 seeds each, per treatment. Seeds of each replication were sowed into a gerbox containing the commercial substrate Bioplant (Pluma ${ }^{\circledR}$ brand), in $2 \mathrm{~cm}$ depth furrows. As initially seeds were separated from fertilizers to facilitate the sowing, to each gerbox was added an amount of fertilizers corresponding to the dose studied in each treatment. For that, the area of the gerbox was computed and then the fertilizer was broadcast spread over the 50 seeds, aiming at simulating a practical field condition. The gerbox were kept under room temperature (between $18{ }^{\circ} \mathrm{C}$ and $32{ }^{\circ} \mathrm{C}$ ) and watered twice a day, by using a watering can. The assessments were performed 21 days after sowing, and results were expressed in percentage (Vieira and Carvalho, 1994).

Emergence speed was determined concomitantly with the emergence test, by daily counting normal seedlings until 21 days after the sowing, according to equation proposed by Maguire (1962) for determining Emergence Speed Index: $(\mathrm{ESI})=\mathrm{E} 1 / \mathrm{N} 1+\mathrm{E} 2 / \mathrm{N} 2+\ldots+\mathrm{En} / \mathrm{Nn}$; where: $\mathrm{En}=$ number of 
normal seedlings computed at first, second, and last counting, respectively; $\mathrm{N} 1, \mathrm{~N} 2$, and $\mathrm{Nn}=$ number of days passed among the sowing and the first, second, and last counting, respectively.

Fresh mass of seedlings (FM) was determined jointly with the seedling emergence test performed under greenhouse conditions. After 21 days from sowing, all plants of each gerbox were cut at soil line and weighed in a $0.0001 \mathrm{~g}$ precision analytical balance. Results were obtained dividing by 50 , the total mass of seedlings in each replication (adapted from Vieira and Carvalho, 1994).

Data were subjected to ANOVA and means were compared by $\mathrm{F}$ test, at $5 \%$ probability; regression analyses were then performed by adjusting equations for the variables assessed and selecting regression with higher correlation coefficient $\left(\mathrm{R}^{2}\right)$ among those that were significant by the $\mathrm{F}$ test. All computations were performed by using the SISVAR computer system, as described by Ferreira (2003).

\section{Results and Discussion}

ANOVA for results of tests performed is shown on Table 2. Interaction among time of contact $x$ dose of fertilizers $x$ source of fertilizers $(T \times D \times S)$ was significant at $1 \%$ probability for: moisture content (MC); first count of germination (FC); viability (Tz); and electrical conductivity (EC). It was also significant at $5 \%$ probability for germination test $(\mathrm{G})$; and nonsignificant for the tests of: emergence (E); emergence speed index (ESI); and fresh mass of seedlings (FMS). In turn, E and ESI have presented significant interactions at $5 \%$ and $1 \%$ probability between time $\mathrm{x}$ dose $(\mathrm{T} \times \mathrm{D})$ and time $\mathrm{x}$ source $(\mathrm{T} \times \mathrm{S})$, respectively. The FMS has presented significant interactions at $1 \%$ probability between time $\mathrm{x}$ source $(\mathrm{T} \times \mathrm{S})$, and at $5 \%$ probability between dose $\mathrm{x}$ source $(\mathrm{D} \times \mathrm{S})$.

Table 2. Results of ANOVA for: germination (G); moisture content (MC); first count of germination (FC); tetrazolium (Tz); seedling emergence (SE); emergence speed index (ESI), electrical conductivity (EC); and fresh mass of seedlings (FMS) data.

\begin{tabular}{|c|c|c|c|c|c|c|c|c|c|c|}
\hline \multicolumn{2}{|c|}{ Variation factor } & $\begin{array}{c}\text { Exposure } \\
\text { time }(\mathrm{T})\end{array}$ & $\begin{array}{l}\text { Fertilizer } \\
\text { dose (D) }\end{array}$ & $\begin{array}{c}\text { Fertilizer } \\
\text { source }(\mathrm{S})\end{array}$ & $\mathrm{T} \times \mathrm{D}$ & $\mathrm{T} \times \mathrm{S}$ & $\mathrm{D} \times \mathrm{S}$ & $\mathrm{T} \times \mathrm{D} \times \mathrm{S}$ & Mean & $\begin{array}{l}\text { CV } \\
(\%)\end{array}$ \\
\hline \multirow{2}{*}{ G } & $\mathrm{Fc}^{*}$ & 102.6230 & 2.9410 & 708.5350 & 2.1210 & 18.4630 & 0.4430 & 1.7790 & \multirow{2}{*}{44.34} & \multirow{2}{*}{18.85} \\
\hline & $\operatorname{Pr}>\mathrm{Fc}$ & 0.0000 & 0.0881 & 0.0000 & 0.0299 & 0.0000 & 0.6427 & 0.0307 & & \\
\hline \multirow{2}{*}{$\mathrm{MC}$} & $\mathrm{Fc}$ & 319.3980 & 10.7170 & 911.0150 & 6.4380 & 20.6050 & 24.8560 & 7.7240 & \multirow{2}{*}{10.06} & \multirow{2}{*}{1.02} \\
\hline & $\operatorname{Pr}>\mathrm{Fc}$ & 0.0000 & 0.0013 & 0.0000 & 0.0000 & 0.0000 & 0.0000 & 0.0000 & & \\
\hline \multirow{2}{*}{$\mathrm{FC}$} & $\mathrm{Fc}$ & 60.9090 & 1.1530 & 391.9010 & 2.0030 & 13.9350 & 0.2690 & 2.5600 & \multirow{2}{*}{33.38} & \multirow{2}{*}{27.37} \\
\hline & $\operatorname{Pr}>\mathrm{Fc}$ & 0.0000 & 0.2844 & 0.0000 & 0.0413 & 0.0000 & 0.7644 & 0.0009 & & \\
\hline \multirow{2}{*}{$\mathrm{Tz}$} & $\mathrm{Fc}$ & 111.9500 & 1.2780 & 375.7330 & 5.0350 & 20.5630 & 3.6380 & 3.4180 & \multirow{2}{*}{56.58} & \multirow{2}{*}{10.49} \\
\hline & $\operatorname{Pr}>\mathrm{Fc}$ & 0.0000 & 0.2597 & 0.0000 & 0.0000 & 0.0000 & 0.0283 & 0.0000 & & \\
\hline \multirow{2}{*}{ SE } & $\mathrm{Fc}$ & 33.3170 & 0.8280 & 268.0430 & 2.3160 & 11.2870 & 2.7010 & 1.4640 & \multirow{2}{*}{44.21} & \multirow{2}{*}{22.79} \\
\hline & $\operatorname{Pr}>\mathrm{Fc}$ & 0.0000 & 0.3642 & 0.0000 & 0.0173 & 0.0000 & 0.0698 & 0.1075 & & \\
\hline \multirow{2}{*}{ ESI } & $\mathrm{Fc}$ & 39.2810 & 0.9680 & 288.6150 & 2.3100 & 10.6580 & 2.4490 & 1.6330 & \multirow{2}{*}{2.35} & \multirow{2}{*}{25.75} \\
\hline & $\operatorname{Pr}>\mathrm{Fc}$ & 0.0000 & 0.3264 & 0.0000 & 0.0176 & 0.0000 & 0.0893 & 0.0561 & & \\
\hline \multirow{2}{*}{$\mathrm{EC}$} & $\mathrm{Fc}$ & 890.7710 & 122.6060 & 21.4520 & 8.2060 & 508.0220 & 66.0300 & 8.6290 & \multirow{2}{*}{235.37} & \multirow{2}{*}{6.89} \\
\hline & $\operatorname{Pr}>\mathrm{Fc}$ & 0.0000 & 0.0000 & 0.0000 & 0.0000 & 0.0000 & 0.0000 & 0.0000 & & \\
\hline \multirow{2}{*}{ FMS } & $\mathrm{Fc}$ & 34.0750 & 6.4460 & 239.3210 & 1.3410 & 6.1290 & 4.0650 & 1.0910 & \multirow{2}{*}{0.03} & \multirow{2}{*}{31.91} \\
\hline & $\operatorname{Pr}>\mathrm{Fc}$ & 0.0000 & 0.0120 & 0.0000 & 0.2187 & 0.0000 & 0.0188 & 0.3643 & & \\
\hline
\end{tabular}

$*_{\mathrm{Fc}}=$ factor computed; and $\mathrm{Pr}=$ probability.

If $\operatorname{Pr}>\mathrm{Fc}$ is lower or equal to 0.01 ; significant at $1 \%$.

If $\operatorname{Pr}>\mathrm{Fc}$ is lower or equal to 0.05 and higher than 0.01 ; significant at $5 \%$.

If $\mathrm{Pr}>\mathrm{Fc}$ is higher than 0.05; non-significant.

For moisture content of seeds (Figure 1) it was observed a positive linear increase on values according to period of contact, independent of doses and sources of fertilizers; although with higher values of moisture content when seeds were exposed to SSp. Several authors have also reported that mixture of seeds with fertilizers produce 
increase on seed moisture content (Soratto et al., 2003; Lima et al., 2009; Lima et al., 2010). Such increase is a consequence of deleterious effect of sulfuric acid, which is used in the processing of phosphatic rock on producing single super phosphate, and ends up on rupturing the seed tegument and causing leakage of electrolytes; thus allowing entry of environmental moisture into the seed (Lima et al., 2009; Soratto et al., 2003). In a general way, however, within this study the variation among treatments was small (from 9.5\% to $11.5 \%$ ), and did not influence on results of the remaining tests. For seeds in general, according to Marcos-Filho (2005), their conservation in open environment during six to eight months should be done with seeds with moisture content between $10 \%$ and $12 \%$.

For values of electrical conductivity (EC) (Figure 2) it

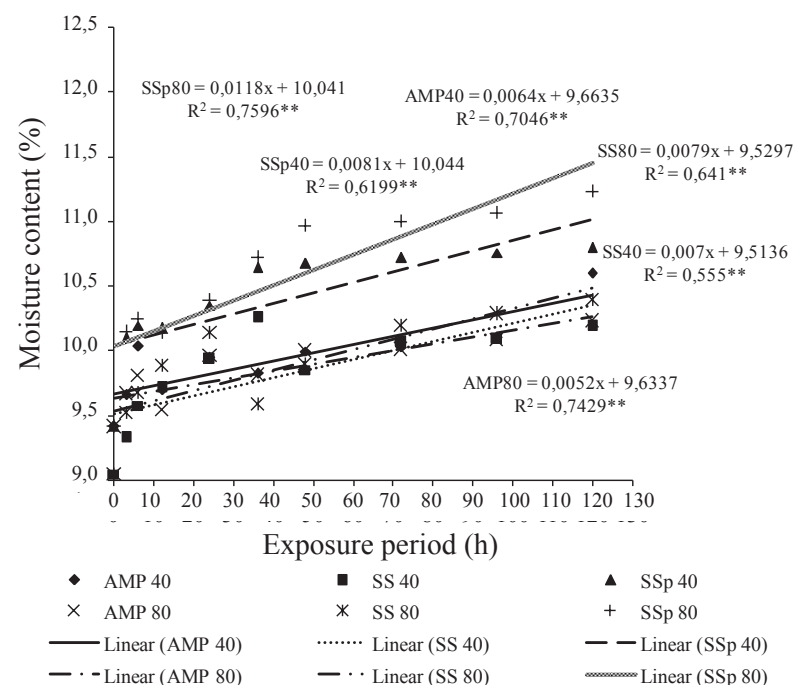

Figure 1. Moisture content of Brachiaria brizantha seeds, cv. Marandu, subjected to different contact periods with the fertilizers: ground granulated ammonium monophosphate (AMP); ground granulated single superphosphate (SS); and single superphosphate powdered (SSp), in the doses of $40 \mathrm{~kg}$ and $80 \mathrm{~kg}$ of $\mathrm{P}_{2} \mathrm{O}_{5}$ per hectare.

The $\mathrm{pH}$ influence on seed tegument can be proved by the chemical scarification with sulfuric acid to promote overcoming of dormancy in seeds, mainly in Leguminosae (Vilela, 2005). Acid scarification causes wear on seed tegument, and thus promotes permeability to the seeds (Perez, 2004), and favors entry of water and gases as well as seed germination. It can also promote, however, increases on leaching of electrolytes from the seeds in consequence of integrity loss of cell membranes. Therefore, the longer the permanence of seeds in contact has also been observed a positive linear increase when seeds remained in contact with SS and SSp, with no interference on AMP for the two doses studied. This result is probably due to the fact that the fertilizer $\mathrm{pH}$ is not very acid, circa 5.28 (Table 1), and thus damaging less the seed tegument. It is known that lower EC values, corresponding to lower lixiviation from seeds, indicate high physiological potential (higher vigor), hence revealing lower intensity of disorganization of cell membranes systems (Vieira et al. 2002). Data herein obtained for EC corroborate results of Soratto et al. (2003), who have observed increases with the larger periods of contact of seeds with fertilizers, in addition to differences among effects of studied fertilizers, where the single superphosphate was responsible for the larger damages to millet seeds as compared to triple superphosphate.

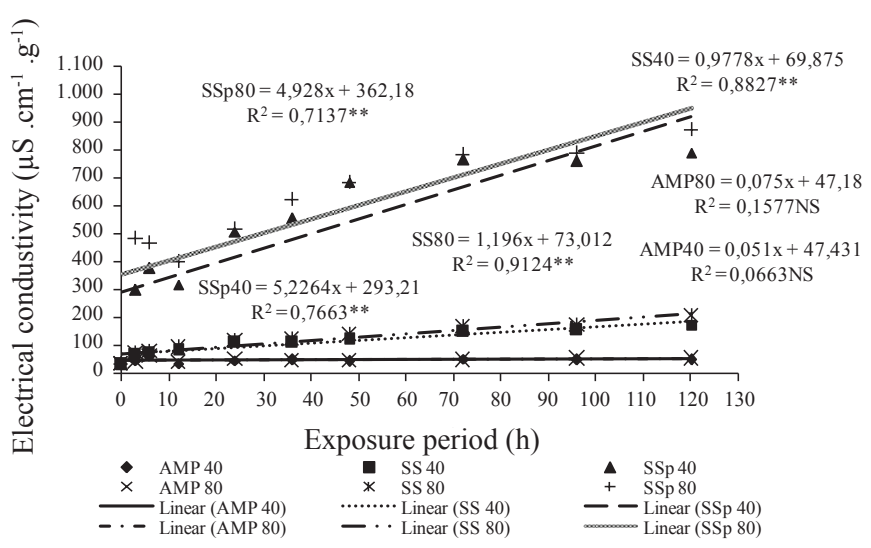

Figure 2. Electrical conductivity of Brachiaria brizantha seeds, cv. Marandu, subjected to different contact periods with the fertilizers: ground granulated ammonium monophosphate (AMP); ground granulated single superphosphate (SS); and single superphosphate powdered (SSp), in the doses of $40 \mathrm{~kg}$ and $80 \mathrm{~kg}$ of $\mathrm{P}_{2} \mathrm{O}_{5}$ per hectare.

with the acid, the worse will be their performance during germination process (Silva et al., 2002).

In a general way, for the tests of germination, first count of germination, and viability, it was verified a decreasing linear negative effect with increasing on time of contact of seeds with fertilizers; independent of source of fertilizer and dose of phosphorus (Figures 3, 4, and 5) being AMP the least prejudicial to the seeds, and SSp the most deleterious. This can be explained by the fact that SSp presents the lowest $\mathrm{pH}$ value 
(3.34), and the highest salinity $\left(920 \mu \mathrm{S} \mathrm{cm}^{-1}\right)$ between the used fertilizers (Table 1); what causes ruptures on the seed tegument and a decrease on their quality. Munns (2002) and Taiz and Zeiger (2006) have affirmed that, besides limitations on absorption of water by seed, the salt causes more significant damages since it penetrates the seed that is in contact with the solution containing it. Thus, the damage

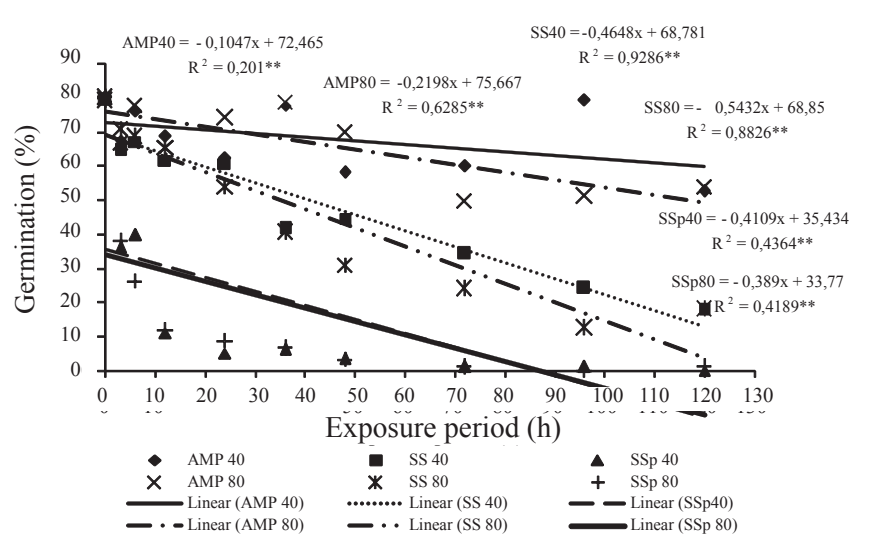

Figure 3. Percentage of germination of Brachiaria brizantha seeds, cv. Marandu, subjected to different contact periods with the fertilizers: ground granulated ammonium monophosphate (AMP); ground granulated single superphosphate (SS); and single superphosphate powdered (SSp), in the doses of $40 \mathrm{~kg}$ and $80 \mathrm{~kg}$ of $\mathrm{P}_{2} \mathrm{O}_{5}$ per hectare.

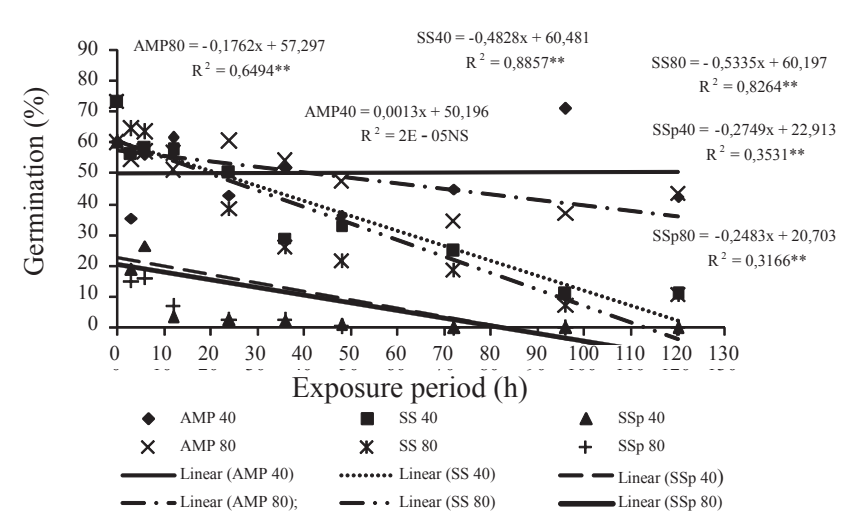

Figure 4. First count of germination of Brachiaria brizantha seeds, cv. Marandu, subjected to different contact periods with the fertilizers: ground granulated ammonium monophosphate (AMP); ground granulated single superphosphate (SS); and single superphosphate powdered (SSp), in the doses of $40 \mathrm{~kg}$ and $80 \mathrm{~kg}$ of $\mathrm{P}_{2} \mathrm{O}_{5}$ per hectare. to seeds is not exclusively the result of reduction on the hydric potential induced by action of an osmotic agent, but also from direct contact with the salt. In addition, once the fertilizers were powdered, the number of their particles was increased, leading to larger contact with the seeds; therefore showing that besides source, the fertilizer granulometry interferes on response.

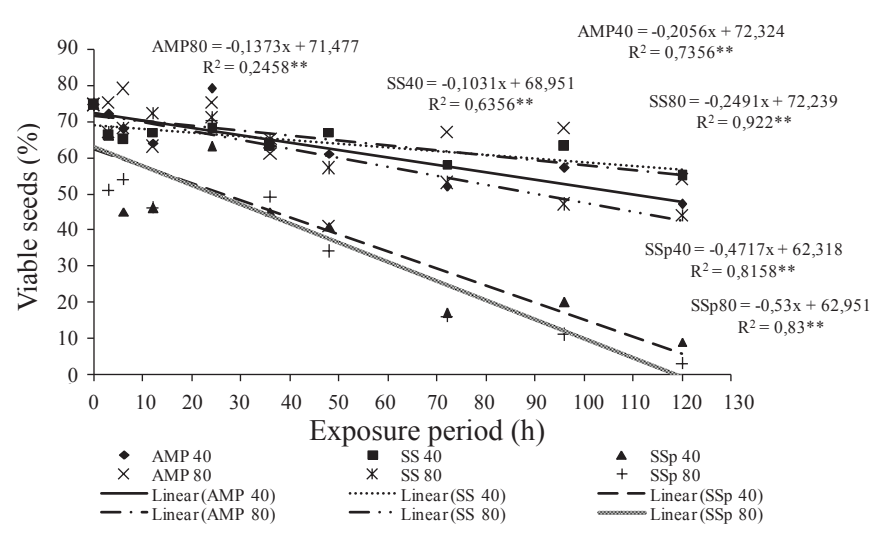

Figure 5. Tetrazolium test performed on seeds of Brachiaria brizantha, cv. Marandu, subjected to different contact periods with the fertilizers: ground granulated ammonium monophosphate (AMP); ground granulated single superphosphate (SS); and single superphosphate powdered (SSp), in the doses of $40 \mathrm{~kg}$ and $80 \mathrm{~kg}$ of $\mathrm{P}_{2} \mathrm{O}_{5}$ per hectare.

The growth stage with higher sensitivity of plants to variations on salinity and $\mathrm{pH}$ is the seedling stage, soon after germination. Notwithstanding, high saline concentration can also affect hydration and absorption of water, which are the initial processes of germination (Marcos-Filho, 2005). Such results corroborate those found by Cavariani et al. (1994), Mateus et al. (2007), Crusciol and Borghi (2007), and Lima et al. (2009) with mixtures of brachiaria seeds and superphosphate. Likewise, results obtained by Lima et al. (2009) and Soratto et al. (2003) who, using triple superphosphate on seeds of brachiaria and millet, have observed decrease on values for first count of germination with increased contact time of seeds with fertilizers.

The fresh mass of seedlings has presented a negative decreasing straight line according to increased contact time with the used fertilizer, being SSp the most prejudicial to seeds (Figure 6). As the dose increased from $40 \mathrm{~kg}$ to $80 \mathrm{~kg}$ of $\mathrm{P}_{2} \mathrm{O}_{5}$ ha $^{-1}$, there was a reduction on fresh mass of seedlings when the fertilizers AMP and SS were used; while for SSp there has been no statistically significant 
interference of doses (Figure 7). This effect on the mass of seedlings was also observed by Soratto et al. (2003), who have obtained a decrease on dry mass of aerial part of millet seedlings, whose seeds were exposed to contact with single superphosphate and triple superphosphate for long periods.

The percentage of emergence and the ESI have presented decrease with the increase on exposure period of the seeds to fertilizers (Figures 8 and 10). The doses of $40 \mathrm{~kg}$ and 80 $\mathrm{kg}$ of de $\mathrm{P}_{2} \mathrm{O}_{5}$ ha $^{-1}$ interfered similarly; while for the sources

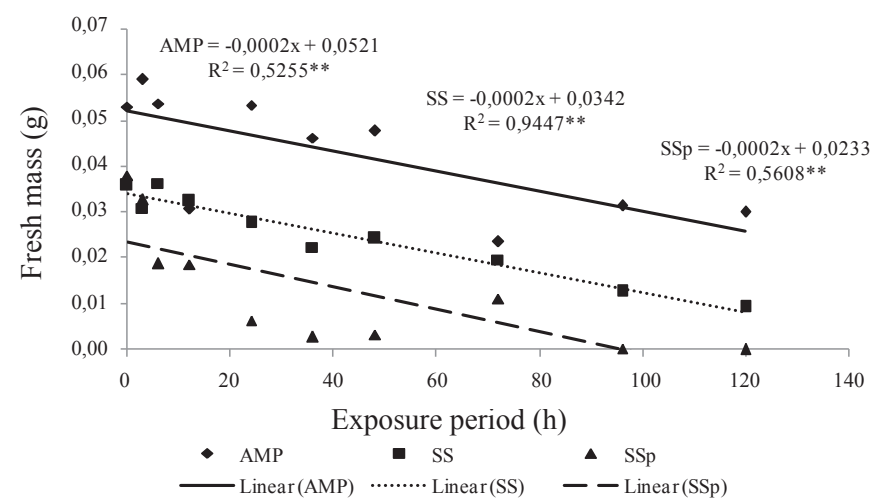

Figure 6. Fresh mass of seedlings originated from seeds of Brachiaria brizantha, cv. Marandu, subjected to different contact periods with the fertilizers: ground granulated ammonium monophosphate (AMP); ground granulated single superphosphate (SS); and single superphosphate powdered (SSp), in the doses of $40 \mathrm{~kg}$ and $80 \mathrm{~kg}$ of $\mathrm{P}_{2} \mathrm{O}_{5}$ per hectare.

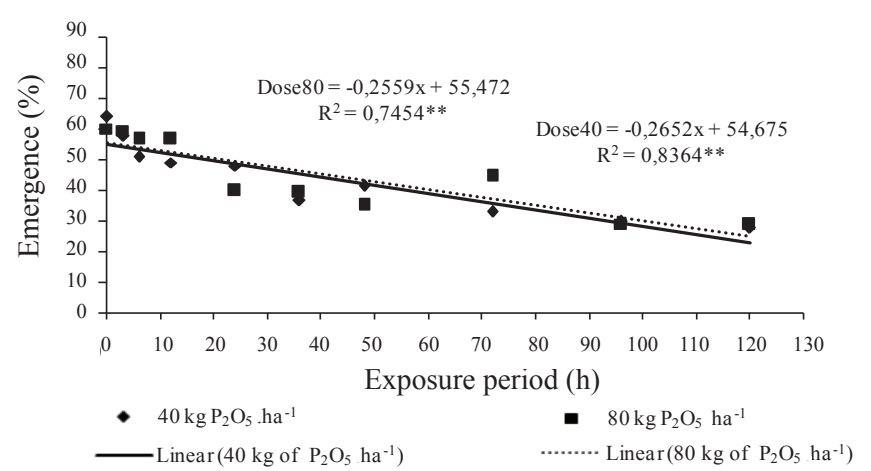

Figure 8. Percentage of emergence of seedlings originated from seeds of Brachiaria brizantha, cv. Marandu, subjected to different contact periods with phosphatic fertilizers in the doses of $40 \mathrm{~kg}$ and $80 \mathrm{~kg}$ of $\mathrm{P}_{2} \mathrm{O}_{5}$ per hectare.
(Figures 9 and 11), the AMP again was less prejudicial to the seeds; and the SSp the most deleterious. Soratto et al. (2003) have also found that emergence and ESI were influenced by periods of contact of millet seeds with phosphatic fertilizers and by the interaction between the type of fertilizer and time of contact with the mixture, with a fast and progressive drop, as contact period increased. Therefore, the source of fertilizer should be selected according to the time at which the seed will remain mixed to fertilizer.

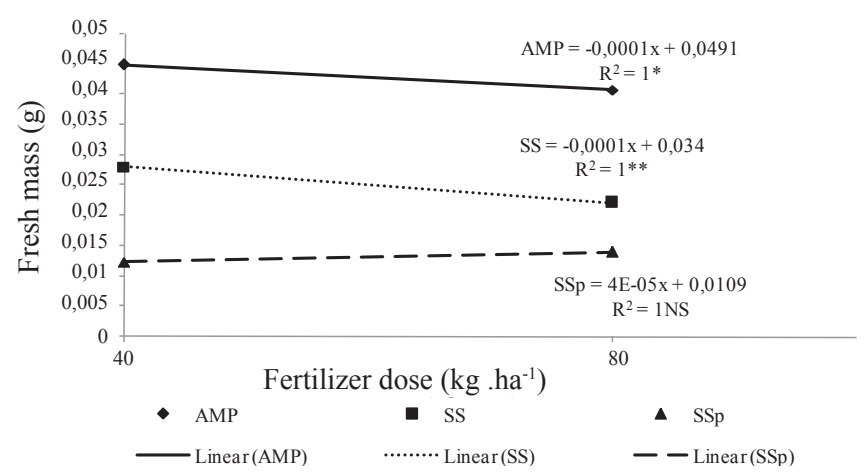

Figure 7. Fresh mass of seedling originated from seeds of Brachiaria brizantha, cv. Marandu, subjected to contact with doses of $40 \mathrm{~kg}$ and $80 \mathrm{~kg}$ of $\mathrm{P}_{2} \mathrm{O}_{5}$ per hectare of the fertilizers: ground granulated ammonium monophosphate (AMP); ground granulated single superphosphate (SS); and single superphosphate powdered (SSp).

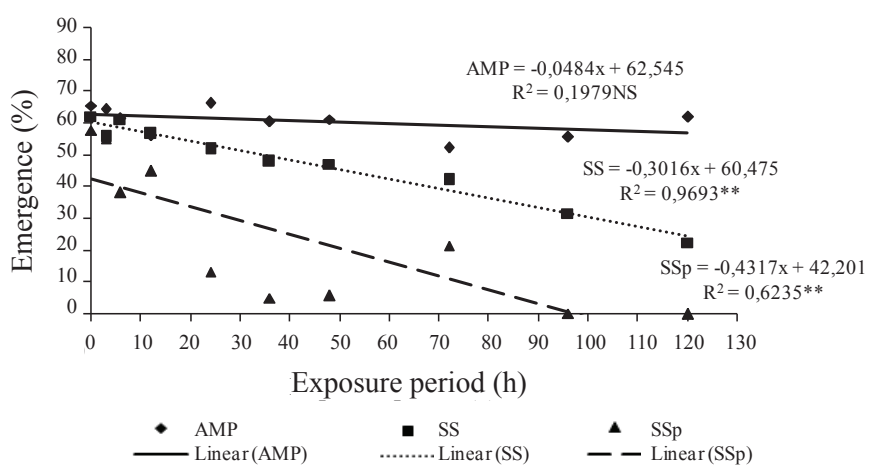

Figure 9. Percentage of emergence of seedlings originated from seeds of Brachiaria brizantha, cv. Marandu, subjected to different contact periods with the fertilizers: ground granulated ammonium monophosphate (AMP); ground granulated single superphosphate (SS); and single superphosphate powdered (SSp). 


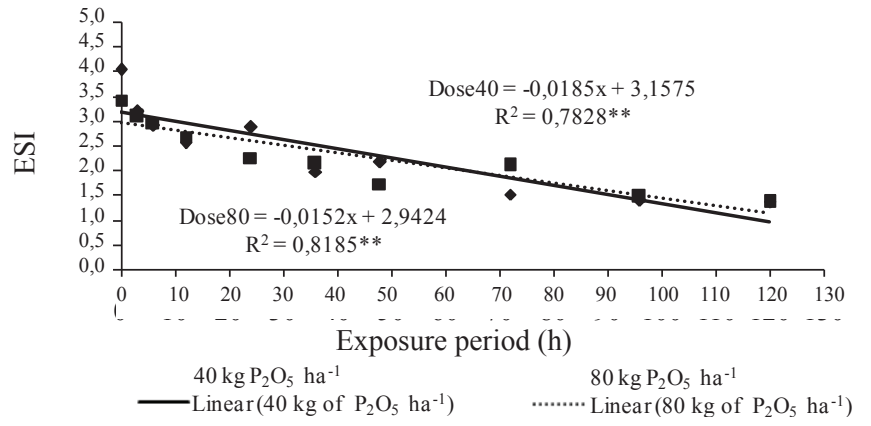

Figure 10. Emergence speed index of seedlings originated from seeds of Brachiaria brizantha, cv. Marandu, subjected to different contact periods with phosphatic fertilizers in the doses of $40 \mathrm{~kg}$ and $80 \mathrm{~kg}$ of $\mathrm{P}_{2} \mathrm{O}_{5}$ per hectare.

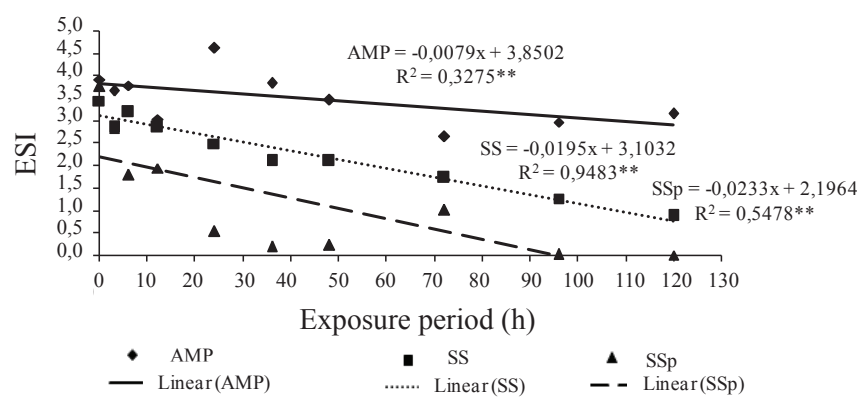

Figure 11. Emergence speed index of seedlings originated from seeds of Brachiaria brizantha, cv. Marandu, subjected to different contact periods with the fertilizers: ground granulated ammonium monophosphate (AMP); ground granulated single superphosphate (SS); and single superphosphate powdered (SSp).

Based on the rules established by the current legislation for seeds in Brazil, it is acceptable the minimum germination of $60 \%$ for categories S1 and S2. This way, according to results obtained by applying the equation previously cited (Figure 3), seeds of brachiaria could be kept in contact with AMP during 119.0 and $71.3 \mathrm{~h}$ at doses of $40 \mathrm{~kg}$ and $80 \mathrm{~kg}$ of $\mathrm{P}_{2} \mathrm{O}_{5} \mathrm{ha}^{-1}$, respectively; for SS, however, such period would be only 18.9 and $16.3 \mathrm{~h}$, at doses of $40 \mathrm{~kg}$ and $80 \mathrm{~kg}$ of $\mathrm{P}_{2} \mathrm{O}_{5} \mathrm{ha}^{-1}$, respectively. By its turn, SSp at the same doses, with only $3 \mathrm{~h}$ contact, seeds would present reductions on germination, reaching values of $34.2 \%$ and $32.6 \%$, respectively; and nil values after 86 $\mathrm{h}$ exposure. However, considering a minimum viability of $60 \%$, brachiaria seeds could be kept in contact with AMP, $\mathrm{SS}$, and SSp at doses of $80 \mathrm{~kg}$ of $\mathrm{P}_{2} \mathrm{O}_{5}$ ha ${ }^{1}$ during 83.6, 49.1, and $5.6 \mathrm{~h}$, respectively; and at dose of $40 \mathrm{~kg}$ of $\mathrm{P}_{2} \mathrm{O}_{5} \mathrm{ha}^{-1}$, during 59.9, 86.8 and $4.9 \mathrm{~h}$, respectively (Figure 5).

It is known that farmers prefer to use granulated fertilizers because it does not become "stony" or "pasty" when mixed to seeds. This way, it is supposable that the seed survival period, when associated to SS and AMP granulated, is a little higher than the periods herein reported, once to facilitate separation from seeds, the granulated fertilizers were ground; thus increasing their total surface as well as their contact with seeds.

\section{Conclusions}

The physiological quality of $B$. brizantha, cv. Marandu, seeds is reduced with increase on exposure period to phosphatic fertilizer; and this reduction depends on the source, dose, and granulometry of fertilizer used.

Phosphatic fertilizers can be related in a decreasing order considering their capacity in impairing physiological quality when mixed with seeds of $B$. brizantha, cv. Marandu in the following forms and order: single superphosphate powdered; followed by ground granulated single superphosphate; and ground granulated ammonium monophosphate.

In considering acceptable that the germination can reach a minimum of $60 \%$, the seeds of $B$. brizantha, cv. Marandu can be kept in contact with ammonium monophosphate granulated and single superphosphate granulated, both at doses of $80 \mathrm{~kg}$ of $\mathrm{P}_{2} \mathrm{O}_{5} \mathrm{ha}^{-1}$, during periods of 71.3 and 16.3 hours, respectively.

\section{References}

ANUALPEC. Anuário da pecuária brasileira. São Paulo: Instituto FNP, 2011. 378p

BARBOSA, R.A. (Ed.). Morte de pastos de braquiária. Campo Grande: EMBRAPA Gado de Corte, 2006. 206 p. (EMBRAPA Gado de Corte, Workshop).

BRASIL. Ministério da Agricultura, Pecuária e Abastecimento. Regras para análise de sementes. Ministério da Agricultura, Pecuária e Abastecimento. Secretaria de Defesa Agropecuária. Brasília: MAPA/ACS, 2009. 395p. http://www.agricultura.gov.br/arq_editor/ file/laborat $\%$ c3\%b3rio/sementes/regras $\% 20$ para $\% 20$ analise $\% 20$ de $\% 20$ sementes.pdf

CAVARIANI, C.; NAKAGAWA, J.; VELINI, E.D. Mistura de fertilizantes fosfatados com sementes de Brachiaria decumbens Stapf e Brachiaria brizantha (Hochst. Ex A. Rich) Stapf. Revista Brasileira de 
Sementes, v.16, n.2, p.163-167, 1994. http://www.abrates.org.br/revista/ artigos/1994/v16n2/artigo11.pdf

CRUSCIOL, C.; BORGHI, E. Consórcio de milho com braquiária: produção de forragem e palhada para o plantio direto. 2007. http://www. agrisus.org.br/arquivos/consorcio_milho_braquiaria_rpd.pdf

EMPRESA BRASILEIRA DE PESQUISA AGROPECUÁRIA EMBRAPA. Centro Nacional de Pesquisa de Pesquisa de Gado de Corte. Forrageira: Brachiaria brizantha, cv. Xaraés. Campo Grande, 2004. (Folheto).

FERREIRA, D.F. SisVar - programa estatístico. Versão 4.2 (Build 39). Lavras: Universidade Federal de Lavras, 2003.

INSTITUTO BRASILEIRO DE GEOGRAFIA E ESTATÍSTICA IBGE. http://www.ibge.gov.br. Acesso em: 20 nov. 2010.

LIMA, E.V.; TAVARES, J.C.S.; AZEVEDO, V.R.; LEITÃO-LIMA, P.S. Mistura de sementes de Brachiaria brizantha com fertilizante NPK. Ciência Rural, v.40, n.2, p.471-474, 2010. http:/www.scielo.br/scielo. php?script=sci_arttext\&pid=s0103-84782010000200035

LIMA, E.V.; TAVARES, J.C.S.; SILVA, E.C.; LEITÃO-LIMA, P.S. Superfosfato triplo como via de distribuição de sementes de Brachiaria brizantha para renovação de pastagens na Amazônia. Revista Brasileira de Zootecnia, v.38, n.5, p.796-800, 2009. http://www.revista.sbz.org.br/ artigo/visualizar.php? artigo $=8137$

MAGUIRE, J.D. Speeds of germination-aid selection and evaluation for seedling emergence and vigor. Crop Science, v.2, p.176, 1962. https:// www.crops.org/publications/cs/abstracts/2/2/cs0020020176

MARCOS-FILHO, J. Fisiologia de sementes de plantas cultivadas. Piracicaba: FEALQ, 2005. 495p.

MATEUS, G.P.; BORGHI, E.; MARQUES, R.R.; VILAS BÔAS, R.L.; CRUSCIOL, C.A.C. Fontes e períodos de contato de fertilizantes e germinação de sementes de Brachiaria brizantha. Revista Brasileira de Ciência do Solo, v.31, n.1, p.177-183, 2007. http://www.scielo.br/scielo. php?script=sci_arttext\&pid=s0100-06832007000100018

MUNNS, R. Comparative physiology of salt and water stress. Plant, Cell and Environment, v.25, n.10, p. 239-250, 2002. http://onlinelibrary.wiley. com/doi/10.1046/j.0016-8025.2001.00808.x/full
NASCIMENTO, J.L.; ALMEIDA, R.A.; SILVA, R.S.M.; MAGALHÃES, L.A.F. Níveis de calagem e fontes de fósforo na produção do capim tanzânia (Panicum maximum jacq. cv. Tanzânia). Pesquisa Agropecuária Tropical, v.32, n.1, p.7-11, 2002. http://www.revistas.ufg.br/index.php/ pat/article/view/2434

PEREZ, S.C.J.G.A. Envoltórios. In: FERREIRA, A.G.; BORGHETTI, F. (Org.). Germinação: do básico ao aplicado. Porto Alegre: Artmed. 2004. p.125-134.

SILVA, A.C.; PORTELA, O.; LORDELLO, A.L.L.; NOGUEIRA, A.C. Efeito do pH sobre o grau de germinação de sementes de Ocotea puberula (Lauraceae). Visão Acadêmica, v.3, n.1, p.19-22, 2002. http:// ojs.c3sl.ufpr.br/ojs2/index.php/academica/article/view/495/408

SORATTO, R.P.; LIMA, E.V.; MAUAD, M.; VILLAS BOAS, R.B.; NAKAGAWA, J. Millet seeds mixed with phosphate fertilizers. Scientia Agricola, v.60, n.3, p.573-579, 2003. http://www.scielo.br/scielo. php?script=sci_arttext\&pid=s0103-90162003000300024

TAIZ, L.; ZEIGER, E. Plant physiology. Redwood City: The Benjamin/ Cummings Publishing Company, 2006. 105p.

VIEIRA, R.D.; CARVALHO, N.M. Testes de vigor em sementes. Jaboticabal: FUNEP, 1994. 164p.

VIEIRA, R.D.; KRZYZANOWSKI, F.C. Teste de Condutividade Elétrica In: KRZYZANOWSKI, F.C.; VIEIRA, R.D.; FRANÇA-NETO, J.B. Vigor de Sementes: conceitos e testes. Londrina: ABRATES, 1999. p.2-1 a 2-24.

VIEIRA, R.D.; PENARIOL, A.L.; PERECIN, D.; PANOBIANCO, M. Condutividade elétrica e teor de água inicial das sementes de soja. Pesquisa Agropecuária Brasileira, v.37, n.9, p.1333-1338, 2002. http://www.scielo. br/scielo.php?pid=s0100-204x2002000900018\&script=sci_arttext

VILELA, H. Pastagem: seleção de plantas forrageiras, implantação e adubação. Viçosa: Aprenda Fácil, 2005. 283p.

WERNER, J.C.; PAULINO, V.T.; CANTARELlA, H.; ANDRADE, N.O.; QUAGGIO, J.A. Forrageiras. In: RAIJ, B. Van; CANTARELLA, H.; QUAGGIO, J.A.; FURLANI, A.M.C. Recomendações de adubação e calagem para o estado de São Paulo. 2.ed. Campinas: Instituto Agronômico \& Fundação IAC, 1997. 285p. (Boletim Técnico, 100). 